\title{
Valvular involvement in ANCA-associated systemic vasculitis: a case report and literature review
}

\author{
Chloé Lacoste ${ }^{1,2}$, Nicolas Mansencal ${ }^{1,2}$, Mona Ben m'rad ${ }^{1,2}$, Catherine Goulon-Goeau ${ }^{1,2}$, Pascal Cohen ${ }^{3,4}$, \\ Loïc Guillevin ${ }^{3,4}$, Thomas Hanslik', ${ }^{1 *}$
}

\begin{abstract}
Background: Antineutrophil cytoplasmic antibodies (ANCA)-associated systemic vasculitides have a variety of presentations, but cardiac valvular involvement is rarely diagnosed and its management is not established.

Case presentation: We report the case of a 44 year old man who presented with an ANCA-associated systemic vasculitis and aortic regurgitation of unusual mechanism. Transthoracic and transesophageal echocardiography disclosed septal hypertrophy preventing a complete closure of the aortic valve and thus responsible for a massive aortic regurgitation. After 4 months of immunosuppressive therapy, the valve lesion did not subside and the patient had to undergo aortic valve replacement. This report also reviews the 20 cases of systemic ANCA-associated vasculitis with endocardial valvular involvement previously reported in the English language medical literature.

Conclusions: Valvular involvement in ANCA-associated systemic vasculitides is rarely reported. Most of these lesions are due to Wegener's granulomatosis and half are present when the diagnosis of vasculitis is made. The valvular lesion is usually isolated, aortic regurgitation being the most frequent type, and often requires valve replacement in the months that follow it's discovery.
\end{abstract}

\section{Background}

Antineutrophil cytoplasmic antibodies (ANCA)-associated systemic vasculitides are a group of small vessel vasculitic syndromes including Wegener's granulomatosis, microscopic polyangiitis and Churg Strauss syndrome. These diseases share a common pathology with focal necrotizing lesions that affect different vessels and organs. Wegener's granulomatosis and Churg Strauss syndrome have additional granulomatous lesions. They have a variety of presentations, but cardiac valvular involvement is rarely reported.

In this report we describe the case of a patient with an ANCA associated systemic vasculitis who presented with aortic regurgitation of unusual mechanism requiring surgical replacement.

\section{Case report}

The patient was a 44-year-old man from Bangladesh who immigrated to France twenty years ago and worked

\footnotetext{
* Correspondence: thomas.hanslik@apr.aphp.fr

'Assistance Publique Hôpitaux de Paris (AP-HP), departments of internal medicine and Cardiology, Ambroise Paré Hospital, 9, avenue Charles-deGaulle, 92100, Boulogne Billancourt, France

Full list of author information is available at the end of the article
}

in several dusty embroidery workshops. Eight months prior to his admission in our hospital, he developed right chronic headaches resisting usual painkillers with right hypoacusia and tinnitus. The right ear examination was consistent with chronic otitis media. A sinus CT scan showed pansinusitis predominating on the right side with right mastoiditis and otitis media. A cerebral MRI showed pachymeningitis of the cerebellopontine angle. Right myringotomy yielded culture-negative drainage. The patient underwent several unsuccessful antibiotic treatments.

Eight months after the onset of the disease, the patient was referred to our ward, complaining, in addition to the other symptoms, of signs of severe intracranial hypertension (persistant right headaches and vomiting), significant weight loss, and a change in his voice. Otorhinological examination showed an unchanged right ear, a paralysis of the left vocal cord responsible for the dysphonia, an abolition of the gag reflex, and a palatal paralysis. The blood pressure was $140 / 65 \mathrm{mmHg}$, the heart rate of $75 \mathrm{bpm}$ and the general examination was normal aside from a three out of four diastolic murmur 
of aortic regurgitation, without any other cardiac signs and a normal electrocardiogram.

An abdominal CT-scan showed a focal thickening of the aortic arch and an identical thickening of the superior mesenteric vein, interpreted as focal aortic and mesenteric vasculitis. A mesenteric panniculitis was also apparent. Laboratory studies included the following values: C-reactive protein $35 \mathrm{mg} / \mathrm{l}$, serum urea nitrogen $4.6 \mathrm{mM} / \mathrm{l}$, creatinine $86 \mathrm{mcM} / \mathrm{l}$, total leukocyte count $10.3 \times 10^{\wedge} 9 /$, polyclonal hypergammaglobulinemia, negative antiphospholipid antibodies, positive antineutrophil cytoplasmic antibodies (ANCA) with positive antimyeloperoxidase antibodies and negative antiproteinase 3 antibodies. The cerebrospinal fluid contained 60 cells per mm3 with $28 \%$ lymphocytes and $1.11 \mathrm{~g} / \mathrm{l}$ of protein; the bacterial, fungal and mycobacterial cultures were negative. The cerebral MRI performed on admission was unchanged. Inferior nasal concha biopsies showed nonspecific inflammation; temporal artery biopsies were normal. Transthoracic and transesophageal echocardiography revealed septal hypertrophy leading to a restriction of aortic valvular closure and thus to massive aortic regurgitation (Figure 1).
The presumptive diagnosis was ANCA-associated systemic vasculitis, most probably Wegener's granulomatosis, with aortic valvular involvement. Treatment with prednisone $(1 \mathrm{mg} / \mathrm{kg})$ and intravenous cyclophosphamide $(700 \mathrm{mg} / \mathrm{m} 2$ every two weeks during one month then every four weeks) was started. With this immunosuppressive therapy the palatal paralysis subsided, the headaches lessened and the patient, slowly regaining weight and energy, was able to return home.

Four months after the beginning of treatment there was an absence of echocardiographic improvement of the septal hypertrophy and aortic regurgitation and the patient had developed congestive heart failure, so the decision was made to perform an aortic Bicarbon ${ }^{\mathrm{TM}^{\mathrm{v}}}$ valve replacement. Upon inspection, the aorta wall and the aortic valve leaflets appeared diffusely thickened. There was a focal thickening of the interventricular septum covered with fibrous tissue. Fibrous tissue was also found on the aortic ring and on the large mitral leaflet. No vegetations were seen. At the end of surgery the patient was in persistent complete heart block requiring a pacemaker implantation.

The microscopic examination of the septum showed chronic remodelling with fibrous and hyaline tissue, and

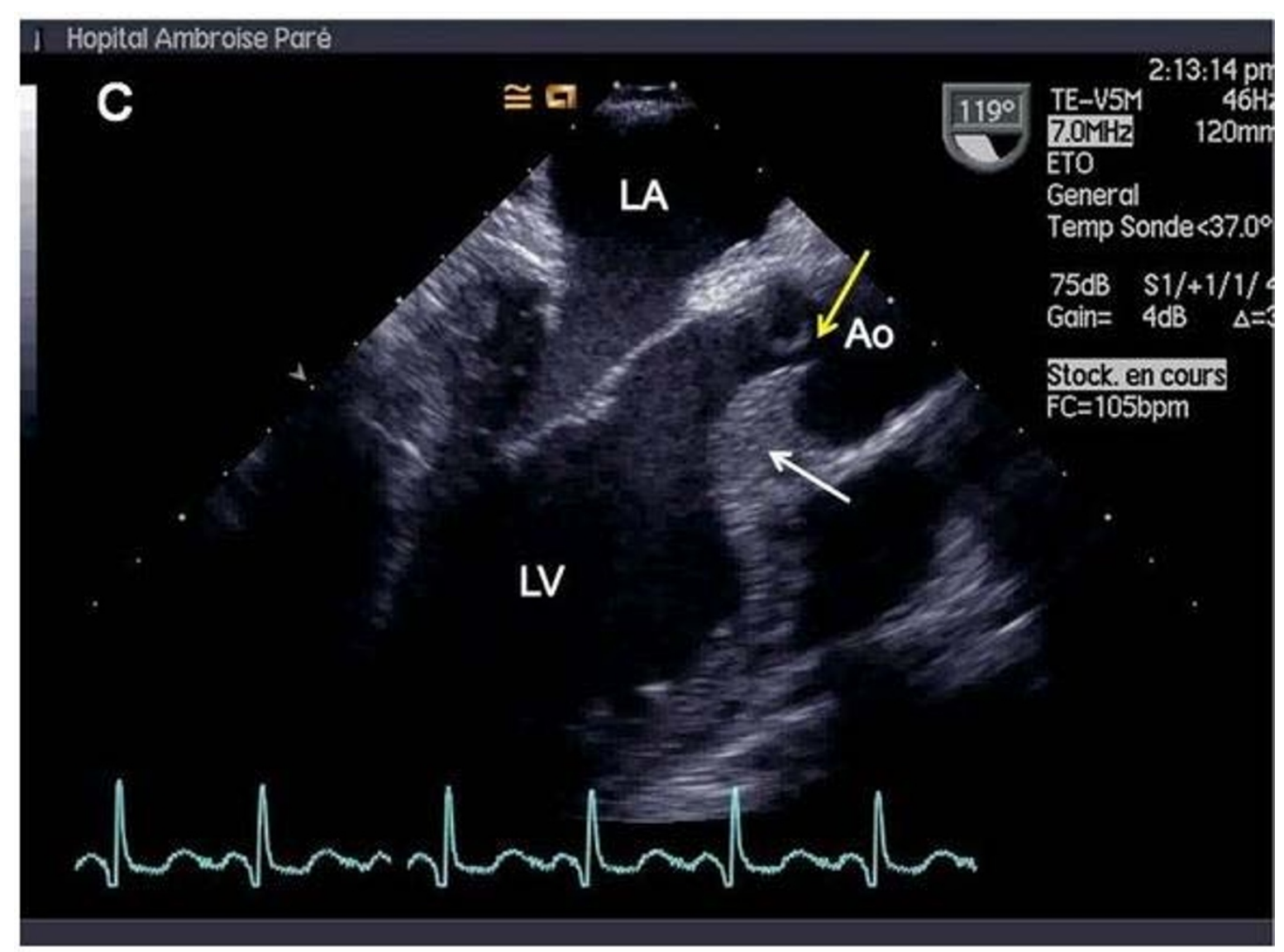

Figure 1 Transesophageal echocardiography showing septal hypertrophy (white arrows) and lack of central coaptation of aortic valve (yellow arrows), resulting in massive aortic regurgitation. $A O=$ aorta. $L A=$ left atrium. $L V=$ left ventricle. 
an intense polymorphic inflammatory infiltrate. Fibrosis as well as a local fragmentation of the elastic fibers was found in the intima and media of the aortic wall. No inflammatory infiltrate nor granuloma were seen in the aortic specimens.

Two years after surgery, the patient is doing well on azathioprine (see Table 1).

\section{Discussion}

In this patient, the diagnosis of ANCA-associated systemic vasculitis, most probably Wegener's granulomatosis, was based on the association of pansinusitis, otitis, mastoiditis, chronic lymphocytic meningitis, aortitis and positive ANCA. This diagnosis was assessed at the National Referral Center for Rare Systemic and Autoimmune Diseases, Necrotizing Vasculitides, and Systemic Sclerosis (Hôpital Cochin, Assistance Publique-Hôpitaux de Paris, Université Paris-Descartes, Paris). Although Pr3-ANCA, found in 70 to $90 \%$ of patients with Wegener's granulomatosis, is often considered to be a seromarker of this disease, MPO-ANCA has been reported to be predominant in Asian patients [1]. This could explain the positive p-ANCA and negative c-ANCA in this patient who is from Bangladesh. The very unusual and unique feature in this patient was the particular mechanism of aortic valve involvement that required a valve replacement.

Using a Pubmed search we looked for reported cases of ANCA-associated systemic vasculitis with a valvular involvement, using the keywords "valve", "cardiac", "heart", "endocarditis", "mitral", "aortic", "tricuspid", "pulmonary", "ANCA", "antineutrophil cytoplasmic antibodies", "Wegener's granulomatosis", "microscopic polyangiitis" and "Churg Strauss" in different combinations. We completed this search by cross-referencing published articles. We thus selected 19 articles in English reporting 20 cases consistent with a systemic ANCAassociated vasculitis with endocardial valvular involvement, i.e. valvular lesions for which infective endocarditis had been excluded and no other aetiology found [2-20].

The general characteristics of the patients and of their vasculitides are reviewed in Table 2 . Their average age tends to be younger than that of the other patients presenting an ANCA-associated-vasculitis (40 versus 47 years old [21]) and the male predominance is greater ( $80 \%$ versus $53 \%$ [21]). One case excepted [19], all reported cases were diagnosed as Wegener's granulomatosis and presented with at least one of the three most common involvements, i.e. renal, pulmonary and otolaryngological. Eye, skin or joint involvement was present in about half the cases. Only 6 patients out of 20 experienced another cardiac lesion, such as pericardial effusion or adhesions $[6,10,15]$, conduction disorders $[4,9,10]$ and coronary artery stenosis [12].

Table 3 details the characteristics of the valvular lesions in the 20 different cases. The most commonly encountered disorder is aortic regurgitation $[4-11,13,14,19,20]$. Seven cases of mitral regurgitation $[3,7,11-13,15,20]$, and one of aortic stenosis [2] were also reported along with two cases of valvular vegetations [16,17], two of a mass involving a mitral leaflet

Table 1 Symptoms, severity score index and main lab and imagery results of the patient described in the case report

\begin{tabular}{|c|c|}
\hline \multirow[t]{2}{*}{ November 2006} & - Persisting facial pain, right chronic headaches resisting usual pain killers \\
\hline & - Cerebral CT-scan: pansinusitis \\
\hline \multirow[t]{3}{*}{ March 2007} & - Same symptoms + right hypoacusia and tinnitus \\
\hline & - Cerebral CT-scan: pansinusitis predominating on the right side with right mastoiditis and otitis medid \\
\hline & - Cerebral MRI: pachymeningitis of the cerebellopontine angle \\
\hline \multirow[t]{13}{*}{ June 2007} & When hospitalized: \\
\hline & - Violent headaches and vomiting: severe intracranial hypertension \\
\hline & - Significant weight loss (- 10 kg) \\
\hline & - Right otitis media \\
\hline & - Paralysis of the left vocal cord (dysphonia), abolition of the gag reflex, and palatal paralysis \\
\hline & - Cerebral MRI: unchanged \\
\hline & - Spinal tap: Aseptic meningitis \\
\hline & - Discovery of the aortic regurgitation \\
\hline & - Abdominal CT-scan: focal aortic and mesenteric vasculitis and mesenteric panniculitis \\
\hline & - Elevated C-reactive protein and leukocyte count \\
\hline & - Polyclonal hypergammaglobulinemia \\
\hline & - pANCA+; anti-MPO +; anti Pr3 - \\
\hline & $-B V A S=23$ \\
\hline June 2009 & BVAS $=2$ \\
\hline
\end{tabular}


Table 2 General characteristics of patients with systemic vasculitides and valvular involvement

\begin{tabular}{|c|c|c|c|c|c|c|c|c|c|c|c|}
\hline Reference & Sex & Age & ANCA & $\begin{array}{l}\text { Vasculitis } \\
\text { Classification }\end{array}$ & Kidney & ENT & $\begin{array}{l}\text { Organ } \\
\text { Lungs }\end{array}$ & $\begin{array}{l}\text { Involvement } \\
\text { Eyes }\end{array}$ & Skin & Joints & $\begin{array}{l}\text { Non-valvular } \\
\text { cardiac } \\
\text { lesion }\end{array}$ \\
\hline Stöllberger [19] & M & 56 & ANCA -, anti-PR3 + & Unknown & Yes & - & - & - & Yes & Yes & - \\
\hline Levine [15] & $M$ & 28 & - & $\begin{array}{c}\text { Wegener's } \\
\text { granulomatosis }\end{array}$ & Yes & Yes & Yes & - & - & - & Yes \\
\hline \multirow[t]{2}{*}{ Davenport [6] } & M & 19 & $\begin{array}{c}\text { c-ANCA }+ \text {, anti-PR3 } \\
+\end{array}$ & $\begin{array}{c}\text { Wegener's } \\
\text { granulomatosis }\end{array}$ & Yes & Yes & Yes & Yes & Yes & Yes & - \\
\hline & M & 53 & $\begin{array}{c}\text { c-ANCA +, anti-PR3 } \\
+\end{array}$ & $\begin{array}{c}\text { Wegener's } \\
\text { granulomatosis }\end{array}$ & Yes & - & - & - & - & - & Yes \\
\hline$\overline{G r a n t ~[10]}$ & $M$ & 32 & c-ANCA + & $\begin{array}{c}\text { Wegener's } \\
\text { granulomatosis }\end{array}$ & - & Yes & - & Yes & Yes & Yes & Yes \\
\hline Goodfield [9] & M & 25 & C-ANCA + & $\begin{array}{c}\text { Wegener's } \\
\text { granulomatosis }\end{array}$ & - & Yes & Yes & - & - & - & Yes \\
\hline Bruno [4] & $\mathrm{F}$ & 63 & ANCA + & $\begin{array}{c}\text { Wegener's } \\
\text { granulomatosis }\end{array}$ & - & Yes & Yes & - & - & - & Yes \\
\hline Herbst [12] & $\mathrm{F}$ & 56 & ANCA - & $\begin{array}{c}\text { Wegener's } \\
\text { granulomatosis }\end{array}$ & - & - & Yes & - & - & Yes & Yes \\
\hline Gerbracht [8] & M & 20 & - & $\begin{array}{c}\text { Wegener's } \\
\text { granulomatosis }\end{array}$ & Yes & Yes & Yes & - & - & - & - \\
\hline Greidinger [11] & M & 15 & C-ANCA + & $\begin{array}{c}\text { Wegener's } \\
\text { granulomatosis }\end{array}$ & Yes & Yes & Yes & - & Yes & Yes & - \\
\hline Leff [14] & M & 17 & c-ANCA + & $\begin{array}{c}\text { Wegener's } \\
\text { granulomatosis }\end{array}$ & - & Yes & Yes & - & Yes & Yes & - \\
\hline Yanda [20] & $\mathrm{F}$ & 77 & - & $\begin{array}{c}\text { Wegener's } \\
\text { granulomatosis }\end{array}$ & Yes & Yes & Yes & Yes & Yes & - & - \\
\hline Dabbagh [5] & $M$ & 16 & - & $\begin{array}{c}\text { Wegener's } \\
\text { granulomatosis }\end{array}$ & Yes & Yes & Yes & Yes & - & - & - \\
\hline Fox [7] & M & 20 & ANCA + & $\begin{array}{c}\text { Wegener's } \\
\text { granulomatosis }\end{array}$ & Yes & Yes & Yes & Yes & Yes & Yes & - \\
\hline Anthony [2] & M & 48 & $\begin{array}{c}\mathrm{c}-\mathrm{ANCA}+\text {, anti-PR3 } \\
+\end{array}$ & $\begin{array}{c}\text { Wegener's } \\
\text { granulomatosis }\end{array}$ & - & Yes & Yes & - & Yes & Yes & - \\
\hline Paik [17] & M & 48 & c-ANCA + & $\begin{array}{c}\text { Wegener's } \\
\text { granulomatosis }\end{array}$ & - & Yes & Yes & - & - & - & - \\
\hline Mishell [16] & M & 65 & ANCA + , anti-PR3 + & $\begin{array}{c}\text { Wegener's } \\
\text { granulomatosis }\end{array}$ & Yes & - & Yes & Yes & Yes & - & - \\
\hline $\begin{array}{l}\text { Ramakrishnan } \\
\text { [18] }\end{array}$ & $F$ & 44 & C-ANCA + & $\begin{array}{c}\text { Wegener's } \\
\text { granulomatosis }\end{array}$ & Yes & - & Yes & - & - & - & - \\
\hline Attaran [3] & M & 52 & - & $\begin{array}{c}\text { Wegener's } \\
\text { granulomatosis }\end{array}$ & - & Yes & - & - & - & - & - \\
\hline Koyalakonda [13] & M & 52 & - & $\begin{array}{c}\text { Wegener's } \\
\text { granulomatosis }\end{array}$ & - & Yes & - & Yes & - & - & - \\
\hline Present report & M & 44 & p-ANCA +, anti-PR3 - & $\begin{array}{c}\text { Wegener's } \\
\text { granulomatosis }\end{array}$ & - & Yes & - & - & - & - & - \\
\hline
\end{tabular}

ANCA: antineutrophil cytoplasmic antibodies; ENT: ear, nose and/or throat involvement; PR3: proteinase-3.

responsible for mild mitral stenosis and moderate mitral regurgitation $[3,13]$, and one of multiple atrial masses without valvular insufficiency or stenosis [18]. Six patients had polyvalvular involvement $[3,7,11,13,16,20]$. Several mechanisms responsible for these valvular lesions have been reported: vegetations $[2,8,16,17,19]$, leaflet thickening $[4,6,9,13,20]$, valvular perforation $[6,14]$ and unique or multiple endocardial masses $[3,9,12,13,18]$.
Half the valvular lesions were present at initial presentation and when the diagnosis of vasculitis was made $[2,6,7,9,12,14,16-18]$. In six of the ten remaining cases, the valvular disease occurred while the patient was on immunosuppressant drugs $[5,8,10,11,13,19]$. In two of these five cases, the onset was less than a week after the treatment was initiated suggesting that the pathological process was already taking place when the drugs were started $[8,19]$. In only four cases valvular disease began 
Table 3 Valvular lesion characteristics in patients with systemic vasculitides

\begin{tabular}{|c|c|c|c|c|c|c|}
\hline Reference & Valve lesion onset & $\begin{array}{l}\text { Valve } \\
\text { lesion }\end{array}$ & $\begin{array}{l}\text { Mechanism of valvular } \\
\text { disease }\end{array}$ & $\begin{array}{l}\text { Valvular } \\
\text { treatment }\end{array}$ & Outcome & $\begin{array}{c}\text { Valve } \\
\text { histology }\end{array}$ \\
\hline $\begin{array}{l}\text { Stöllberger } \\
\text { [19] }\end{array}$ & After 3 days steroïds & $A R$ & Vegetation & - & AVR & $\begin{array}{l}\text { Non } \\
\text { specific }\end{array}$ \\
\hline Levine [15] & $\begin{array}{l}\text { After } 6 \text { weeks of ENT } \\
\text { signs no IST }\end{array}$ & $M R$ & $?$ & - & Died of heart failure & - \\
\hline \multirow[t]{2}{*}{ Davenport [6] } & $\begin{array}{l}\text { At initial } \\
\text { presentation }\end{array}$ & $A R$ & $\begin{array}{l}\text { Leaflet perforation and } \\
\text { tissue disruption }\end{array}$ & 1 year IST & AVR & $\begin{array}{l}\text { Non } \\
\text { specific }\end{array}$ \\
\hline & $\begin{array}{l}\text { At initial } \\
\text { presentation }\end{array}$ & $A R$ & Thickened leaflets & IST & Worse, awaiting AVR & - \\
\hline Grant [10] & After 1 year of CYC & $A R$ & Dilation of ascending aorta & 20 Mo IST & AVR & $\begin{array}{l}\text { Non } \\
\text { specific }\end{array}$ \\
\hline Goodfield [9] & $\begin{array}{l}\text { At initial } \\
\text { presentation }\end{array}$ & $A R$ & $\begin{array}{c}\text { Thickened leaflets and mass } \\
\text { obstructing the left ventricular } \\
\text { outflow tract }\end{array}$ & $\begin{array}{l}6 \text { weeks } \\
\text { IST }\end{array}$ & $\begin{array}{c}\text { Thickening \& mass disappeared. AVR } \\
\text { because of LV dilatation \& shrunken } \\
\text { Ao leaflet }\end{array}$ & $\begin{array}{l}\text { Non } \\
\text { specific }\end{array}$ \\
\hline Bruno [4] & $\begin{array}{l}3 \text { years after illness } \\
\text { onset, no IST }\end{array}$ & $A R$ & $\begin{array}{l}\text { Thickened, rigid and retracted } \\
\text { leaflets }\end{array}$ & - & AVR & Specific \\
\hline Herbst [12] & $\begin{array}{l}\text { At initial } \\
\text { presentation }\end{array}$ & $M R$ & Mass involving a leaflet & & $M V R \& A V R$ & Specific \\
\hline Gerbracht [8] & After 5 days CYC & $A R$ & Vegetation & IST & Complete resolution & - \\
\hline \multirow{2}{*}{$\begin{array}{l}\text { Greidinger } \\
{[11]}\end{array}$} & After 3 weeks CYC & $A R$ & $?$ & IST & Lesion unchanged & - \\
\hline & & MR & $?$ & IST & Lesion unchanged & - \\
\hline Leff [14] & $\begin{array}{l}\text { At initial } \\
\text { presentation }\end{array}$ & $A R$ & Perforation of 2 leaflets & 1 year IST & Ao valve repair: homograft & - \\
\hline \multirow[t]{2}{*}{ Yanda [20] } & $\begin{array}{l}1 \text { year after initial } \\
\text { presentation, } \\
\text { no IST }\end{array}$ & $A R$ & Thickened leaflet & - & AVR & $\begin{array}{l}\text { Non } \\
\text { specific }\end{array}$ \\
\hline & & MR & Thickened leaflet & IST & $?$ & - \\
\hline Dabbagh [5] & After 3 weeks CYC & $A R$ & $?$ & IST & $?$ & - \\
\hline \multirow[t]{2}{*}{ Fox [7] } & $\begin{array}{l}\text { At initial } \\
\text { presentation }\end{array}$ & $A R$ & $\begin{array}{l}\text { Prolapsing Ao leaflets and } \\
\text { discrete Ao leaflet deficiency }\end{array}$ & $5 \mathrm{Mo} \mathrm{IST}$ & AVR & $\begin{array}{l}\text { Non } \\
\text { specific }\end{array}$ \\
\hline & & $\mathrm{MR}$ & $?$ & IST & $?$ & - \\
\hline Anthony [2] & $\begin{array}{l}\text { At initial } \\
\text { presentation }\end{array}$ & AS & Vegetation & $3 \mathrm{Mo} \mathrm{IST}$ & Lesion unchanged & - \\
\hline Paik [17] & $\begin{array}{l}\text { At initial } \\
\text { presentation }\end{array}$ & $\begin{array}{c}\text { Ao } \\
\text { vegetations }\end{array}$ & Vegetation & IST & $?$ & \\
\hline Mishell [16] & $\begin{array}{l}\text { At initial } \\
\text { presentation }\end{array}$ & $\begin{array}{l}\text { Ao and } M \\
\text { vegetations }\end{array}$ & Vegetations & IST & Died & $\begin{array}{l}\text { Non } \\
\text { specific }\end{array}$ \\
\hline $\begin{array}{l}\text { Ramakrishnan } \\
{[18]}\end{array}$ & $\begin{array}{l}\text { At initial } \\
\text { presentation }\end{array}$ & M masses & $\begin{array}{c}\text { Multiple masses in atriums and } \\
\text { on MP }\end{array}$ & $\begin{array}{l}\text { Few days } \\
\text { IST }\end{array}$ & Died & - \\
\hline Attaran [3] & $\begin{array}{c}30 \text { years after illness } \\
\text { onset, IST? }\end{array}$ & $\begin{array}{l}\text { Ao and } M \\
\text { mass, MR, } \\
\text { MS }\end{array}$ & $\begin{array}{c}\text { Mass involving an Ao and an M } \\
\text { leaflet }\end{array}$ & IST & $M V R \& A V R$ & $\begin{array}{l}\text { Non } \\
\text { specific }\end{array}$ \\
\hline $\begin{array}{l}\text { Koyalakonda } \\
{[13]}\end{array}$ & $\begin{array}{l}\text { Not at initial } \\
\text { presentation and } \\
\text { under treatment }\end{array}$ & $\begin{array}{l}\text { MS \& MR } \\
\quad \text { AR }\end{array}$ & $\begin{array}{l}\text { M mass involving leaflet } \\
\text { Thickened Ao valve }\end{array}$ & $\begin{array}{l}\text { IST } \\
\text { IST }\end{array}$ & $\begin{array}{l}\text { Mass unchanged: MVR } \\
\text { AR progressed: AVR }\end{array}$ & $\begin{array}{l}\text { Non } \\
\text { specific }\end{array}$ \\
\hline Present report & $\begin{array}{l}\text { At initial } \\
\text { presentation }\end{array}$ & $A R$ & $\begin{array}{c}\text { Septal thickening: incomplete } \\
\text { closure of Ao valve, thickened } \\
\text { leaflets }\end{array}$ & 4 Mo IST & AVR & $\begin{array}{l}\text { Non } \\
\text { specific }\end{array}$ \\
\hline
\end{tabular}

?: Unknown; AR: aortic regurgitation; Ao: aortic; AS: aortic stenosis; AVR: aortic valve replacement; CYC: cyclophosphamide; IST: immunosuppressive therapy; LV: left ventricular; M: mitral; Mo: months; MP: mitral prothesis; MR: mitral regurgitation; MS: mitral stenosis; MVR: mitral valve replacement.

more than a year after the first signs of the vasculitis $[3,4,10,20]$.

A valve replacement was required in most cases $[3,4,6,7,9,10,12,13,19,20]$. In only two cases did immunosuppressive therapy allow a complete resolution of the valvular lesions [8,9]; and in one of these [9] the patient had nonetheless to undergo an aortic valve replacement because of secondary left ventricular dilatation and a shrunken leaflet.

The pathological findings were nonspecific in almost all cases; i.e. showing inflammation and/or scarring without abscess, giant cells, vasculitis, or granuloma. In 
two cases, granuloma, necrosis and/or micro abscess were described in the valvular tissue $[4,12]$.

To conclude, although it might be underdiagnosed due to the lack of patent clinical signs and the absence of systematic screening, valvular involvement in ANCAassociated systemic vasculitides is rarely reported. Most of these valvular lesions are due to Wegener's granulomatosis and half are present when the diagnosis of vasculitis is made. The valvular lesion is usually unique, aortic regurgitation being the most frequent type, and often requires valve replacement in the months that follow its discovery.

\section{Consent}

written informed consent was obtained from the patient for publication of this case report and any accompanying images.

\section{Acknowledgements \\ We are thankful to Dr Rebecca J. Spencer, MD-PhD, for editing the manuscript.}

\section{Author details \\ ${ }^{1}$ Assistance Publique Hôpitaux de Paris (AP-HP), departments of internal medicine and Cardiology, Ambroise Paré Hospital, 9, avenue Charles-de- Gaulle, 92100, Boulogne Billancourt, France. ' Université Versailles Saint Quentin en Yvelines, UFR de Médecine "Paris Ile-de-France Ouest", 9 boulevard d'Alembert, 78280 Guyancourt, France. ${ }^{3}$ Assistance Publique Hôpitaux de Paris (AP-HP), National Referral Center for Rare Systemic and Autoimmune Diseases, Necrotizing Vasculitides, and Systemic Sclerosis, Department of Internal Medicine, Cochin Hospital, 27, rue du Faubourg Saint-Jacques, 75014, Paris, France. ${ }^{4}$ Université Paris Descartes, 12, rue de l'Ecole de médecine 75006 Paris, France.}

\section{Authors' contributions}

CL wrote the paper; NM conducted the cardiological expertise; CGG, conducted the neurological expertise; MB,PC and LG conducted the patient's evaluation at the National Referral Center for Rare Systemic and Autoimmune Diseases, Necrotizing Vasculitides, and Systemic Sclerosis (Hôpital Cochin, Assistance Publique-Hôpitaux de Paris, Université ParisDescartes, Paris); TH is taking care of this patient and supervised the writing of this paper. All the authors have made substantial contributions to acquisition and analysis of data and have been involved in revising the manuscript critically for intellectual content.

All authors read and approved the final manuscript.

\section{Competing interests}

The authors declare that they have no competing interests.

Received: 25 August 2010 Accepted: 23 February 2011

Published: 23 February 2011

\section{References}

1. Chen M, Yu F, Zhang Y, Zou WZ, Zhao MH, Wang HY: Characteristics of Chinese patients with Wegener's granulomatosis with antimyeloperoxidase autoantibodies. Kidney Int 2005, 68(5):2225-2229.

2. Anthony DD, Askari AD, Wolpaw T, McComsey G: Wegener granulomatosis simulating bacterial endocarditis. Arch Intern Med 1999, 159(15):1807-1810.

3. Attaran S, Desmond M, Ratnasingham J, Scawn N, Pullan DM: Mitral valve involvement in Wegener's granulomatosis. Ann Thorac Surg 2010, 90(3):996-997.

4. Bruno P, Le Hello C, Massetti M, Babatasi G, Saloux E, Galateau F, Khayat A: Necrotizing granulomata of the aortic valve in Wegener's disease. $J$ Heart Valve Dis 2000, 9(5):633-635
5. Dabbagh S, Chevalier RL, Sturgill BC: Prolonged anuria and aortic insufficiency in a child with Wegener's granulomatosis. Clin Nephrol 1982, 17(3):155-159.

6. Davenport A, Goodfellow J, Goel S, Maciver AG, Walker P: Aortic valve disease in patients with Wegener's granulomatosis. Am J Kidney Dis 1994, 24(2):205-208.

7. Fox AD, Robbins SE: Aortic valvulitis complicating Wegener's granulomatosis. Thorax 1994, 49(11):1176-1177.

8. Gerbracht DD, Savage RW, Scharff N: Reversible valvulitis in Wegener's granulomatosis. Chest 1987, 92(1):182-183.

9. Goodfield NE, Bhandari S, Plant WD, Morley-Davies A, Sutherland GR: Cardiac involvement in Wegener's granulomatosis. Br Heart J 1995, 73(2):110-115.

10. Grant SC, Levy RD, Venning MC, Ward C, Brooks NH: Wegener's granulomatosis and the heart. Br Heart J 1994, 71(1):82-86.

11. Greidinger EL, Lemes $V$, Hellmann DB: Cardiac valve disease in Wegener's granulomatosis. J Rheumatol 1996, 23(8):1485-1487.

12. Herbst A, Padilla MT, Prasad AR, Morales MC, Copeland JG: Cardiac Wegener's granulomatosis masquerading as left atrial myxoma. Ann Thorac Surg 2003, 75(4):1321-1323.

13. Koyalakonda SP, Krishnan U, Hobbs WJ: A rare instance of multiple valvular lesions in a patient with Wegener's granulomatosis. Cardiology 2010, 117(1):28-30

14. Leff RD, Hellman RN, Mullany CJ: Acute aortic insufficiency associated with Wegener granulomatosis. Mayo Clin Proc 1999, 74(9):897-899.

15. Levine $\mathrm{H}$, Madden TJ: Wegener's granulomatosis; report of a case. Am Heart J 1957, 53(4):632-637.

16. Mishell JM: Cases from the Osler Medical Service at Johns Hopkins University: cardiac valvular lesions in Wegener's granulamatosis. Am J Med 2002, 113(7):607-609.

17. Paik ML, MacLennan GT, Seftel AD: Embolic testicular infarction secondary to nonbacterial thrombotic endocarditis in Wegener's granulomatosis. J Urol 1999, 161(3):919-920.

18. Ramakrishnan S, Narang R, Khilnani GC, Kurian S, Saxena A, Sharma S, Talwar KK: Wegener's granulomatosis mimicking prosthetic valve endocarditis. Cardiology 2004, 102(1):35-36.

19. Stollberger C, Finsterer J, Zlabinger GJ, Weihsengruber F, Redtenbacher S, Bonner G, Herkner K, Deutsch M: Antineutrophil cytoplasmic autoantibody-negative antiproteinase 3 syndrome presenting as vasculitis, endocarditis, polyneuropathy and Dupuytren's contracture. J Heart Valve Dis 2003, 12(4):530-534.

20. Yanda RJ, Guis MS, Rabkin JM: Aortic valvulitis in a patient with Wegener's granulomatosis. West J Med 1989, 151(5):555-556.

21. Puechal $X$ : Antineutrophil cytoplasmic antibody-associated vasculitides. Joint Bone Spine 2007, 74(5):427-435.

\section{Pre-publication history}

The pre-publication history for this paper can be accessed here: http://www.biomedcentral.com/1471-2474/12/50/prepub

doi:10.1186/1471-2474-12-50

Cite this article as: Lacoste et al:: Valvular involvement in ANCAassociated systemic vasculitis: a case report and literature review. $B M C$ Musculoskeletal Disorders 2011 12:50.

\section{Submit your next manuscript to BioMed Central and take full advantage of:}

- Convenient online submission

- Thorough peer review

- No space constraints or color figure charges

- Immediate publication on acceptance

- Inclusion in PubMed, CAS, Scopus and Google Scholar

- Research which is freely available for redistribution 